\title{
Response of Chickpea (Cicer arietinum L.) to Foliar Application of Ethrel, Kinetin and Boron
}

\author{
P. Menaka*, Y. Ashoka Rani, K.L. Narasimha Rao, \\ P. Hareesh Babu and M. Lal Ahamed
}

Department of Crop Physiology, Agricultural College, Bapatla - 522 101, India

\section{Keywords}

Ethrel, Kinetin, Boron, Chickpea, Growth parameters, Yield attributes

Article Info

Accepted:

12 October 2018

Available Online:

10 November 2018

\section{A B S T R A C T}

A Field experiment was conducted at college form, agricultural college bapatla in clay loam soils during Rabi 2013-14 to study the effects of Ethrel, kinetin and boron foliar application on physiology of growth, development and yield of chickpea (Var. KAK 2) in randomized block design with eight treatments viz., 250ppm Ethrel at 25 DAS $\left(\mathrm{T}_{1}\right), 10$ ppm kinetin at $35 \mathrm{DAS}\left(\mathrm{T}_{2}\right), 0.25 \%$ boron at $45 \mathrm{DAS}\left(\mathrm{T}_{3}\right), 250 \mathrm{ppm}$ Ethrel at 25DAS + 10 ppm Kinetin at 35DAS $\left(\mathrm{T}_{4}\right), 10 \mathrm{ppm}$ Kinetin at 35DAS $+0.25 \%$ boron at $45 \mathrm{DAS}\left(\mathrm{T}_{5}\right)$, $250 \mathrm{ppm}$ Ethrel at 25DAS $+0.25 \%$ boron at $45 \mathrm{DAS}\left(\mathrm{T}_{6}\right), 250 \mathrm{ppm}$ Ethrel at $25 \mathrm{DAS}+10$ ppm Kinetin at $35 \mathrm{DAS}+0.25 \%$ boron at $45 \mathrm{DAS}\left(\mathrm{T}_{7}\right)$ and control (without sprays- $\left.\mathrm{T}_{8}\right)$ in three replications. The spray of $10 \mathrm{ppm}$ kinetin at $35 \mathrm{DAS}+0.25 \%$ boron at $45 \mathrm{DAS}\left(\mathrm{T}_{5}\right)$ exhibited higher performance in increasing plant height by $19.8 \%$ over control followed by $\mathrm{T}_{2}(11.3 \%)$. The highest number of branches plant ${ }^{-1}(67.3 \%)$ over control was obtained with $10 \mathrm{ppm}$ kinetin spray at 35 DAS $\left(\mathrm{T}_{2}\right)$. The number of flowers plant ${ }^{-1}$ increased with Ethrel (16.3\%), kinetin (12\%) and Ethrel + kinetin (11.9\%) sprays compared to control. the less Flower drop and flower abortion was recorded in plants treated with 250ppm Ethrel compared to control. The spray of $0.25 \%$ boron enhance total dry matter plant ${ }^{-1}$ by $62.4 \%$ and spray of $250 \mathrm{ppm}$ Ethrel at $25 \mathrm{DAS}+0.25 \%$ boron at 45 DAS enhanced it by $49 \%$ over control.0.25\% boron spray at 45 DAS and spray of $250 \mathrm{ppm}$ Ethrel at 25 DAS+ $0.25 \%$ boron at 45 DAS exhibited higher CGR ( $97.5 \%$ and $80.3 \%$ respectively) compared to control during pod maturation (60 DAS to maturity). Spray of kinetin and Ethrel + kinetin enhanced RGR by 22.8 and $17.7 \%$ during flowering and pod development compared to control, while during pod maturation spray of boron and Ethrel + boron enhanced the RGR. The spray of boron resulted in an increase of 24.7 and $12.6 \%$ in pod number plant ${ }^{-1}$ and 100 seed weight respectively; spray of Ethrel at $25 \mathrm{DAS}+$ Boron at 45 DAS increased the pod yield and seed yield ha ${ }^{-1}$ by 26.5 and $25.6 \%$ respectively compared to control.

\section{Introduction}

Pulses and grain legumes are major sources of dietary protein. Chickpea (Cicer arietinum L.) is one of the major pulse crops grown in India and third largest produced food legume globally, after common bean (Phaseolus vulgaris L.) and field pea (Pisum sativum L.). The cultivation of chickpea has number of problems like extended period of flowering and pod formation and their shedding. The productivity of chickpea is found to be poor 
due to heavy flower drop, pod shedding, poor seed set and source limitation. Despite of high yielding potential and various advantages of chickpea, the yield per unit area of the crop is low which indicates that there is great scope to improve the productivity potential by using suitable measures particularly, the use of plant growth regulators and micronutrients.

Plant growth regulators added in small amounts, modify the natural growth regulatory system right from seed germination to senescence and play a role in key metabolic processes. Besides this, growth regulators help to achieve optimum vegetative growth, alter the plant architecture, regulate the shedding of reproductive organs and result in yield improvement. Ethrel application decreased the flower and pod shedding and resulted in increased fruit size, translocation of photosynthates from source-sink at pod development stage and thereby increased yield in chickpea (Saxena et al., 2007). Kinetin plays a crucial role as promoter of cell division and act in the induction and development of meristematic centers leading to the formation of organs, mainly shoots and it has counteracting role in apical dominance. Kinetin application promotes lateral shoot formation from lateral buds and increases the number of shoots (Sohair et al., 2006), seed yield plant $^{-1}$ and yield attributes (Sadak et al., 2013)

Apart from this, the micronutrients also play an important role in regulating plant metabolic processes. Boron is an important micronutrient, plays role in carbohydrate metabolism, translocation of sugars from source to sink, flower retention, pollen fertility and germination, pod setting, seed development, yield and its components. Thus, the requirement of boron appears more essential for reproductive development than vegetative (Nalini Pandey and Bhavana Gupta., 2013).
In consideration of the importance of these aspects, investigate the effect of Ethrel, Kinetin and Boron foliar application on physiology of growth, development and yield of chickpea.

\section{Materials and Methods}

The field experiment was conducted during the Rabi season of 2013-14 at Agricultural College Farm, Bapatla in clay loam soil $\left(\mathrm{P}^{\mathrm{H}}\right.$ $7.8, \mathrm{EC}-0.29 \mathrm{dS} \mathrm{m}^{-1}$, organic carbon $5.1 \mathrm{~g} \mathrm{~kg}^{-}$ 1, $198 \mathrm{~kg}$ nitrogen ha ${ }^{-1}, 33.0 \mathrm{~kg} \mathrm{P}_{2} \mathrm{O}_{5} \mathrm{ha}^{-1}$ and

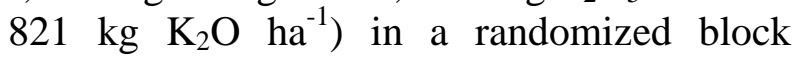
design with three replications and eight treatments. The seeds of chickpea variety kak 2 were sown by dibbling. Nitrogen and phosphorous were applied as per the scheduled recommendation. The crop was supplied with adequate water by following the recommended irrigation schedule.

Foliar sprays of growth regulators Ethrel and Kinetin and micronutrient Boron were given to the crop alone [Ethrel @ 250 ppm at 25DAS $\left(\mathrm{T}_{1}\right)$; Kinetin @ 10 ppm at 35DAS $\left(\mathrm{T}_{2}\right)$; Boron@0.25\% at 45DAS (T3)] and in combinations [Ethrel @ 250 ppm at 25DAS + Kinetin@10 ppm at 35DAS $\left(\mathrm{T}_{4}\right)$, Kinetin@ 10 ppm at 35DAS + Boron @ 0.25\% at 45DAS $\left(\mathrm{T}_{5}\right)$, Ethrel @ $250 \mathrm{ppm}$ at 25DAS + Boron@0.25\% at 45DAS $\left(\mathrm{T}_{6}\right)$ and Ethrel @ 250 ppm at 25DAS + Kinetin @ 10 ppm at 35DAS + Boron @ 0.25\% at 45DAS $\left(\mathrm{T}_{7}\right)$ ], without foliar sprays considered as control $\left(\mathrm{T}_{8}\right)$. The experimental field was maintained weed free and pest free by following appropriate weed control and plant protection measures. The data on Growth and development (plant height, no. of branches, no. of flowers produced plant ${ }^{-1}$, no. of flowers dropped plant ${ }^{-1}$, no. of flowers aborted plant ${ }^{-1}$, total plant dry matter, CGR and RGR) were collected by using techniques of nondestructive and destructive growth analysis. Yield and yield components were measured at 
the time of harvest. The data were analysed statistically by following pansa sukhathme (1978).

\section{Results and Discussion}

\section{Growth and development}

Foliar sprays of plant growth regulators Ethrel, Kinetin and micronutrient Boron significantly influenced the plant height (Table 1). The highest plant height $(49.0 \mathrm{~cm})$ was observed with the spray of $10 \mathrm{ppm}$ Kinetin at 35DAS $+0.25 \%$ Boron at 45DAS $\left(\mathrm{T}_{5}\right)$ followed by $10 \mathrm{ppm}$ Kinetin spray at 35 DAS $\left(\mathrm{T}_{2}-45.5 \mathrm{~cm}\right)$ which was on par with rest of the treatments except the spray of Ethrel alone $(41.5 \mathrm{~cm})$ and control $(40.9 \mathrm{~cm})$. The lowest plant height was recorded with control $(40.9 \mathrm{~cm})$. The increase in plant height with kinetin was $11.3 \%$ and with kinetin + boron spray was $19.8 \%$. The effect of other spray treatments was on par with each other.

Kinetin plays crucial role as promoter of cell division and act in the induction and development of meristematic tissues, thus increased the shoot length and number of nodes. Similarly the increase in shoot length was reported by Sadak et al., (2013) in Fababean and Zahir (2001) in rice. Boron also increased plant height by formation of new plant cells, elevated level of IAA, development of meristematic tissues, cell elongation and tissue differentiation and sugar transportation. Bangar et al., (2010) also reported increase in plant height in soyabean with Boron application.

All spray treatments significantly increased the number of branches at different stages over control (Table 1). The spray of $10 \mathrm{ppm}$ Kinetin at 35 DAS $\left(\mathrm{T}_{2}-18.9\right)$ resulted in higher number of branches than all other treatments and which was increased by 67.3 per cent over control. The next higher value (14.9) was observed with the spray of $10 \mathrm{ppm}$ Kinetin at $35 \mathrm{DAS}+0.25 \%$ Boron at 45DAS $\left(\mathrm{T}_{5}\right)$, which was on par with $\mathrm{T}_{7}-14.7, \mathrm{~T}_{3}-14.3, \mathrm{~T}_{6}-13.6$ and $T_{1}-12.3$.The lowest value observed in control $\left(\mathrm{T}_{8}-11.3\right)$.

The increased number of branches with Kinetin might be due to its counteracting role in apical dominance. Naeem et al., (2004) reported that Kinetin at high level promotes lateral shoot formation from lateral buds and increase number of shoots in lentil.

The data with respect to number of flowers per plant indicated significant differences in between the treatments (Table). There was increase in number of flowers at 45 DAS and afterwards the number declined compared to control. Among the treatments Ethrel, Kinetin and Ethrel + Kinetin sprays recorded 16.3, 12.0 and 11.9 per cent increase in number of flowers respectively. It might be due to the involvement of Ethrel in the induction of early flowering, restricting the problem of flower drop, flower abortions, increased photosynthetic efficiency and increased translocation of sugars to the point of axillary buds as reported by Khan et al., (2000) in mustard. Similar results were observed by Saxena et al., 2007 in chickpea.

Among the spray treatments, number of flowers dropped per plant of chickpea differed significantly (Table 1). The number of flowers dropped was more in control (3.0) i.e. no foliar spray. Among the spray treatments, it varied from 2.1 to 2.8 in Ethrel sprayed plants with an average of 2.5 and it was less compared to control (3.0).

The more number of dropped flowers in control plants might be due to nutrient deficiency and hormonal imbalances and ultimately reduced translocation of assimilates to reproductive parts. The less Flower drop with Ethrel spray might be due to its effect in 
preventing excessive vegetative growth and diverting the metabolite towards reproductive growth, stimulation of flowering, fruiting and reduction of premature abscission of flowers. Saxena et al., (2007) proved that Ethrel application at low (250 ppm) and medium (500 ppm) concentrations at pre-flowering and mid flowering stages was useful in eliminating flower abscission in chickpea.

Number of flowers aborted per plant of chickpea with foliar application of Ethrel, Kinetin and Boron was significantly differed between the treatments (Table 1). The least flower abortion was recorded in plants treated with $250 \mathrm{ppm}$ Ethrel it varied from 2.6 to 3.2 with an average of 2.9. The highest number of aborted flowers was recorded with control (3.4).

Khan et al., (2000) reported the involvement of ethylene in diverse array of cellular, developmental and stress released processes in plants, such as promotion of flowering, restricting the problem of flower drop and flower abortions, increased photosynthetic efficiency and increased translocation of sugars to floral organs in mustard. The data on total dry matter plant ${ }^{-1}$ as influenced by the plant growth regulators and nutrients varied significantly in all the treatments (Table 1). Highest value $\left(\mathrm{T}_{3}-24.2 \mathrm{~g}\right.$ plant $\left.^{-1}\right)$ of total dry matter plant ${ }^{-1}$ was obtained in foliar spray of $0.25 \%$ Boron at 45 DAS which exhibited an increase of 62.4 per cent over control, which was on par with $250 \mathrm{ppm}$ Ethrel at 25DAS + $0.25 \%$ Boron at 45DAS $\left(\mathrm{T}_{6}-22.2 \mathrm{~g} \mathrm{plant}^{-1}\right)$. The lower value was recorded in control plants $\left(\mathrm{T}_{8}-14.9 \mathrm{~g}\right.$ plant $\left.^{-1}\right)$.

Ali and Mishra (2001) reported that highest amount of total dry matter accumulation observed with Boron application might be due its role in translocation of photosynthetic assimilates which reflected towards the total dry matter production. Similar results were given by Rezaul Kabir et al., (2013) in groundnut. At the same time, the application of Ethrel caused increase in total plant dry matter, which might be due to its involvement in a diverse array of cellular, developmental and stress-released processes in plants. Nagasubramanium et al., (2007) stated that Ethrel caused increased photosynthetic efficiency, dry matter and yield in Baby corn. Total dry matter per plant and SLW in groundnut was increased by Ethrel application (Thakur et al., 2008).

Significant differences were recorded in Crop Growth Rate (CGR) between the treatments (Table 1). It is a measure of rate of biomass production per unit of ground area per unit time. During 60 DAS-maturity, among the treatments, $0.25 \%$ Boron at 45 DAS $\left(\mathrm{T}_{3}-14.02\right.$ $\left.\mathrm{g} \mathrm{m}^{-2} \mathrm{~d}^{-1}\right)$ recorded higher CGR $(97.5 \%)$ which was on par with $250 \mathrm{ppm}$ Ethrel $+0.25 \%$ Boron at 45 DAS $\left(\mathrm{T}_{6^{-}} 12.80 \mathrm{~g} \mathrm{~m}^{-2} \mathrm{~d}^{-1}\right)$, which was 80.3 per cent compared to control. The lower value with control $\left(\mathrm{T}_{8}-7.10 \mathrm{~g} \mathrm{~m}^{-2} \mathrm{~d}^{-}\right.$ $\left.{ }^{1}\right)$ This increase of CGR by Boron spray might be due to the increase of pod dry matter and total plant dry matter. This might be associated with increase in translocation of photosynthetic assimilates and utilization of major and minor nutrients, which responded in increasing plant dry matter (Oyinlola, 2007).

Effect of plant growth regulators and nutrients on relative growth rate (RGR) is presented in Table 1. There was a decline in RGR as the crop growth advanced and maximum RGR was noticed in chickpea over control in all treatments during 30-45 DAS. Among the treatments, $10 \mathrm{ppm}$ Kinetin at $35 \mathrm{DAS}+$ $0.25 \%$ Boron at 45 DAS $\left(\mathrm{T}_{5}-74.2 \mathrm{mg} \mathrm{g}^{-1} \mathrm{~d}^{-1}\right)$ recorded higher RGR by 22.8 percent compared to control; followed by $250 \mathrm{ppm}$ Ethrel at 25DAS + 10 ppm Kinetin at 35 DAS $+0.25 \%$ Boron at 45DAS $\left(\mathrm{T}_{7}-71.1 \mathrm{mg} \mathrm{g}^{-1}\right.$ $\mathrm{d}^{-1}$ ), which was 17.71 percent more compared to control. 
Table.1 Effect of foliar sprays of Ethrel, Kinetin and Boron on growth and development of chickpea

\begin{tabular}{|c|c|c|c|c|c|c|c|c|}
\hline TREATMENTS & $\begin{array}{l}\text { Plant } \\
\text { Height } \\
\text { (cm) }\end{array}$ & $\begin{array}{c}\text { Number } \\
\text { of } \\
\text { Branches } \\
\text { pt }^{-1}\end{array}$ & $\begin{array}{c}\text { Number } \\
\text { of } \\
\text { flowers } \\
\text { pt }^{-1}\end{array}$ & $\begin{array}{c}\text { Number } \\
\text { of } \\
\text { flowers } \\
\text { dropped } \\
\text { pt }^{-1}\end{array}$ & $\begin{array}{c}\text { Number } \\
\text { of } \\
\text { flowers } \\
\begin{array}{c}\text { Aborted } \\
\text { pt }^{-1}\end{array}\end{array}$ & $\begin{array}{c}\text { Total } \\
\text { plant dry } \\
\text { weight (g } \\
\left.\text { pt }^{-1}\right)\end{array}$ & $\begin{array}{c}\text { CGR } \\
\text { (60 DAS - } \\
\text { maturity) }\end{array}$ & $\begin{array}{c}\text { RGR } \\
\text { (30 DAS } \\
- \text { 45DAS })\end{array}$ \\
\hline $\begin{array}{c}\mathrm{T}_{1}-250 \mathrm{ppm} \text { Ethrel } \\
\text { at } 25 \mathrm{DAS}\end{array}$ & 41.5 & 12.3 & 22.8 & 2.1 & 2.6 & 15.8 & 7.63 & 62.8 \\
\hline $\begin{array}{c}\mathrm{T}_{2}-10 \mathrm{ppm} \text { Kinetin } \\
\text { at } 35 \mathrm{DAS}\end{array}$ & 45.5 & 18.9 & 24.1 & 2.1 & 2.7 & 16.3 & 6.49 & 65.7 \\
\hline $\begin{array}{c}\mathrm{T}_{3}-0.25 \% \text { Boron at } \\
45 \text { DAS }\end{array}$ & 43.7 & 14.3 & 24.9 & 1.1 & 1.7 & 20.2 & 14.02 & 67.1 \\
\hline $\mathrm{T}_{4}$-Ethrel + Kinetin & 41.9 & 11.5 & 23.6 & 2.4 & 2.9 & 16.5 & 7.51 & 67.2 \\
\hline $\mathrm{T}_{5}-$ Kinetin + Boron & 49.0 & 14.9 & 24.7 & 2.4 & 3.0 & 18.2 & 9.77 & 74.2 \\
\hline $\mathrm{T}_{6}-$ Ethrel + Boron & 42.5 & 13.6 & 27.9 & 2.2 & 2.6 & 20.3 & 12.80 & 67.1 \\
\hline $\begin{array}{c}\mathrm{T}_{7} \text {-Ethrel+ } \\
\text { Kinetin+Boron }\end{array}$ & 43.6 & 14.7 & 25.3 & 2.0 & 2.5 & 18.0 & 10.03 & 71.1 \\
\hline $\mathrm{T}_{8}-$-Control & 40.9 & 11.3 & 21.8 & 2.5 & 3.1 & 14.9 & 7.10 & 60.4 \\
\hline SEm \pm & 1.2 & 0.1 & 1.1 & 0.2 & 0.2 & 1.1 & 0.45 & 2.5 \\
\hline CD & 3.7 & 2.9 & 3.3 & 0.5 & 0.5 & 3.4 & 1.38 & 7.7 \\
\hline CV (\%) & 4.9 & 12.0 & 7.8 & 12.5 & 11.7 & 11.1 & 8.36 & 6.5 \\
\hline
\end{tabular}

Table.2 Effect of foliar sprays of Ethrel, Kinetin and Boron on yield attributes and yield of chickpea

\begin{tabular}{|c|c|c|c|c|}
\hline TREATMENTS & $\begin{array}{l}\text { Number of } \\
\text { pods per } \\
\text { plant) }\end{array}$ & $\begin{array}{c}100 \text { Seed } \\
\text { weight }\end{array}$ & $\begin{array}{c}\text { Pod yield } \\
\text { (kg/ha) }\end{array}$ & $\begin{array}{c}\text { Seed yield } \\
\text { (kg/ha) }\end{array}$ \\
\hline $\mathrm{T}_{1}-250 \mathrm{ppm}$ Ethrel & 21.3 & 31.4 & 3318.1 & 1783.2 \\
\hline $\mathrm{T}_{2}-10 \mathrm{ppm}$ Kinetin & 22.0 & 30.6 & 3148.6 & 1730.9 \\
\hline $\mathrm{T}_{3}-0.25 \%$ Boron & 24.2 & 33.9 & 3697.1 & 1993.3 \\
\hline $\mathrm{T}_{4}-$ Ethrel + Kinetin & 20.9 & 30.7 & 3249.5 & 1685.3 \\
\hline $\mathrm{T}_{5}-$ Kinetin + Boron & 22.3 & 31.6 & 3420.5 & 1848.5 \\
\hline $\mathrm{T}_{6}$-Ethrel + Boron & 23.4 & 32.5 & 3784.2 & 2021.8 \\
\hline $\mathrm{T}_{7}$-Ethrel + Kinetin + Boron & 22.4 & 32.1 & 3527.8 & 1903.1 \\
\hline $\mathrm{T}_{8}-$ Control & 19.4 & 30.1 & 2991.5 & 1609.7 \\
\hline SEm \pm & 0.9 & 0.70 & 147.2 & 78.0 \\
\hline CD & 2.7 & 2.13 & 446.4 & 236.5 \\
\hline CV (\%) & 7.0 & 3.84 & 7.5 & 7.4 \\
\hline
\end{tabular}


The lowest RGR value was observed with control $\left(\mathrm{T}_{8}-60.4 \mathrm{mg} \mathrm{g}^{-1} \mathrm{~d}^{-1}\right)$. The RGR of chickpea plants with Ethrel spray varied from 62.8 to $67.1 \mathrm{mg} \mathrm{g}^{-1} \mathrm{~d}^{-1}$ (with an average of $65.0 \mathrm{mg} \mathrm{g}^{-1} \mathrm{~d}^{-1}$ ), with Kinetin spray varied from 65.7 to $74.2 \mathrm{mg} \mathrm{g}^{-1} \mathrm{~d}^{-1}$ (with an average of $70.0 \mathrm{mg} \mathrm{g}^{-1} \mathrm{~d}^{-1}$ ) and with combination of both Kinetin and Ethrel spray varied from 67.2 to $71.1 \mathrm{mg} \mathrm{g}^{-1} \mathrm{~d}^{-1}$ (with an average of $\left.69.2 \mathrm{mg} \mathrm{g}^{-1} \mathrm{~d}^{-1}\right)$.

This increase of RGR by Kinetin spray might be due to it increases the accumulation of dry matter in root, stem and leaves. It also enhances the leaf number and leaf area. All these aspects reflected increase in RGR values. Similar observations reported by Naeem et al., (2004) in lentil.

Ethrel spray increase RGR might be due to accumulation of high dry matter in root, leaf and pod and ultimately increase in total plant dry matter.

These reflect higher RGR values. This might be associated with significant increase in assimilate partitioning in varied growth stages by virtue of increased photosynthetic efficiency. Similar observations reported by Nagasubramanium et al., (2007) in baby corn and Kashiwagi et al., (2007) in chickpea.

\section{Yield components and yield}

At maturity, sprays of Ethrel, Kinetin and Boron resulted in significant increase in number of pods per plant (Table 2). Among the treatments, $0.25 \%$ Boron at $45 \mathrm{DAS}\left(\mathrm{T}_{3^{-}}\right.$ 24.2) recorded higher number of pods per plant, followed by $250 \mathrm{ppm}$ Ethrel at $25 \mathrm{DAS}$ $+0.25 \%$ Boron at 45 DAS $\left(\mathrm{T}_{6}-23.4\right)$.

The foliar sprays of Boron and Ethrel + Boron resulted in an increase of 24.7 and 20.6 per cent in number of pods per plant over control. Boron is important in cell division and helps in germination and growth of pollen grains, sugar translocation, and movement of growth regulators within the plant. Similar results were also reported by Singh (2004) and Aparna Hamsa and Puttaiah (2012).

Abbas (1991) stated that ethylene released from Ethrel decreased the flower and pod shedding, increased the pod set and thereby resulted in better pod yield in chickpea. Similar results were also reported by Saxena et al., (2007).

There were significant differences in 100 seed weight due to foliar sprays of growth regulators and micronutrients (Table 2). $0.25 \%$ Boron at 45 DAS ( $\left.\mathrm{T}_{3}-33.9 \mathrm{~g}\right)$ possessed the highest test weight, which was resulted an increase of 12.6 per cent in test weight over control.

The influence of Boron spray on test weight might be due to the increased translocation of assimilates from source to sink as reported by Singh and Vidyachowdari (1996) in groundnut. Similar results were also reported by Ahlawat et al., 2007 in chickpea.

The data related to pod yield per hectare revealed significant differences in all the treatments with the foliar application of Ethrel, Kinetin and Boron (Table 2). The pod yield ranged from 2991.5 to $3784.2 \mathrm{~kg} \mathrm{ha}^{-1}$. Among the treatments higher pod yield $\left(3784.2 \mathrm{~kg} \mathrm{ha}^{-1}\right)$ was recorded in $250 \mathrm{ppm}$ Ethrel at 25DAS $+0.25 \%$ Boron at 45DAS and it reported an increase of 26.5 per cent compared to control and it was followed by $0.25 \%$ Boron at 45 DAS $\left(\mathrm{T}_{3}-3697.1 \mathrm{~kg}\right.$ $\left.\mathrm{ha}^{-1}\right)$. Lower seed yield per ha was recorded in Control $\left(\mathrm{T}_{8}-2991.5 \mathrm{~kg} \mathrm{ha}^{-1}\right)$.

Boron spray enhances the pod yield as evident from the study. This might be due to its positive influence on number of pods per plant and pod set and mobilization of assimilate reserves to the sink. These results fall in line with the findings of Ali and Mishra 
(2001) and Shil et al., (2007) in chickpea and Adkine et al., (2011) in soya bean. Ethrel also increases mobilization of reserve food materials to the developing sink through increase in hydrolyzing and oxidizing enzyme activities and leads to increase in yield. Lone et al., (2010) reported that ethrel in association with nitrogen significantly increased pods per plant, seed yield of Indian mustard.

Variation in the treatments was noticed for seed yield by foliar application of Ethrel, Kinetin and Boron (Table 2). Among the treatments, enhanced seed yield was recorded in the treatment, $250 \mathrm{ppm}$ Ethrel at 25DAS $+0.25 \%$ Boron at 45DAS $\left(\mathrm{T}_{6}-2021.8 \mathrm{~kg} \mathrm{ha}^{-1}\right)$ by 25.6 per cent compared to control which was on par with $0.25 \%$ Boron at 45 DAS $\left(\mathrm{T}_{3}-1993.3 \mathrm{~kg}\right.$ $\left.\mathrm{ha}^{-1}\right)$.

A higher amount of seed yield was observed with Boron spray due to its positive influence on pod set, number of pods per plant, pod weight, 100 seed weight and mobilization of assimilate reserves to the sink. These results sound same with the findings of Ali and Mishra (2001) and Adkine et al., (2011). Similarly Ethrel also contributed increase in pod yield and seed yield, by promotion of flowering, restricting the problem of flower and pod abscission and results the allocation of assimilates in sink. These results were in agreement with the findings of Khan et al., (2000) in mustard and Saxena et al., (2007) in chickpea.

All the foliar sprays $250 \mathrm{ppm}$ Ethrel at 25DAS, $10 \mathrm{ppm}$ Kinetin at 35 DAS and $0.25 \%$ Boron at 45 DAS improved yield and yield components. But, mainly foliar spray of $250 \mathrm{ppm}$ Ethrel at 25 DAS $+0.25 \%$ Boron at 45 DAS significantly enhanced the pod yield and seed yield per hectare in chickpea.

\section{References}

Abbas, S. 1991. Biosynthesis pathways as control points in ethylene regulated flower and fruit drop and seed absorption in chickpea. Grain Legumes, Feb. 9-11, organized by Indian Society of Genetics and Plant Breeding, IARI, New Delhi.

Adkine, P.M., Mankar, D.D., Khandait, V.M., Bhandare, V.L and Nawlakhe, S.M. 2011. Effect of boron, molybdenum and potassium nitrate on growth, yield and economics of soybean. Journal of Soil and Crops. 21(1): 116-123.

Ahlawat, I.P.S., Gangaiah, B. and Zadid, A. M. 2007. Nutrient management in chickpea. In: Chickpea breeding and management (Yadav S.S., Redden R., Chenv W., Sharma B., eds). CAB International, Wallingford, Oxon, United Kingdom. p. 213-232.

Ali, M and Mishra, J.P. 2001. Effect of foliar nutrition of boron and molybdenum on chickpea. Indian Journal Pulses Research. 14 (1): 41-43.

Aparna Hamsa and Puttaiah, E.T. 2012. Residual effect of zinc and boron on growth and yield of French bean (Phaseolus vulgaris L.)-rice (Oryza sativa L.) cropping system. International Journal of Environmental Sciences. 3 (1): 167-171.

Bangar, S.S., Khandagale, G.B., Pawar, G.S., Khedekar, S.B and Pandit, M.D. 2010. Growth, dry matter and yield of soybean as influenced by different levels of sulphur and boron. Annals of Plant Physiology. 24 (2): 220-221.

Kashiwagi, J., Krishnamurthy, L., Serraj, R., Crouch, J.H and Panwar J.D.S. 2007. Rapid and reliable screening technique for root traits in chickpea. Journal of Food Legumes. 20 (1): 67-70.

Khan, N.A., Lone, N.A and Samiullah. 2000. Response of mustard (Brassica juncea L.) to applied nitrogen with or without ethrel spray under non-irrigated conditions. Journal of Agronomy and Crop Science. 183: 1-4.

Lone, N.A., Mir, M.R., Ashraf Bhat, M., Haleema Ashraf., Bhat, K. A., Rashid, R., Asma Hassan., Nasier Ahmad., Akhtar, S., Bhat, J.A. and Habib, M. (2010). Effect of ethrel and nitrogen on nitrate 
reductase activity, photosynthesis, biomass and yield of mustard (Brassica juncea L. Czern and Coss). Recent Research in Science and Technology 2 (2): $25-26$.

Naeem, M., Iram Bhatti., Raza Hafeez Ahmad and Yasin Ashraf, M. 2004. Effect of some growth hormones $\left(\mathrm{GA}_{3}\right.$, IAA and kinetin) on the morphology and early or delayed initiation of bud of lentil (Lens culinaris Medik). Pakistan Journal of Botany. 36 (4): 801-809.

Nagasubramaniam, A., Pathmanabhan, G and Mallika, V. 2007. Studies on improving production potential of baby corn with foliar spray of plant growth regulators. Annals of Plant Physiology. 21 (2): 154157.

Nalini Pandey and Bhavana Gupta. 2013. The impact of foliar boron sprays on reproductive biology and seed quality of black gram. Journal of Trace Elements in Medicine and Biology. 27: 58-64.

Oyinlola, E.Y. 2007. Effect of 'B' fertilizer on yield and oil content of three sunflower cultivars in the Nigerian savanna. Journal of Agronomy. 6: 421-426.

Panse, M and Sukhatme, K. 1978. Statistical methods for agriculture workers. Indian Council of prearl millet (Pennisetum glaucum L.) II. Effect on yield and yield components. Annals of Arid Zone. 37 (1): 59-67.

Rezaul Kabir., Sabina Yeasmin., Mominul Islam A.K.M and Abdur Rahman Sarkar, M. 2013. Effect of $\mathrm{P}, \mathrm{Ca}$ and $\mathrm{B}$ on the growth and yield of groundnut (Arachis hypogea L.). International Journal of Bio-Science and Biotechnology.5 (3): 51.
Sadak, Sh. Mervat. Dawood, M.G., Bakry, B.A and El-Karamany M.F. 2013 Synergistic effect of Indole Acetic Acid and Kinetin on performance, some biochemical constituents and yield of faba bean plant grown under newly reclaimed sandy soil. Journal of Agricultural Sciences. 9 (4): 335-34

Saxena D.C, Abbas, S and Sairam R.K. 2007. Effect of ethrel on reproductive efficiency in chickpea. Indian Journal of Plant Physiology. 12 (2):162-167.

Shil N.C., Noor S., Hossain M.A., 2007. Effects of boron and molybdenum on the yield of chickpea. J Agric Rural Develop (Gazipur) 5, 17-24.

Singh, M.V. 2004. Micronutrient deficiencies in Indian soils and field usable practices for their correction. IFA International Conference on Micronutrients, Feb, 2324, 2004, at New Delhi.

Singh, A.L. and Vidyachowdari. 1996. Use of zincated and boronated super phosphates and mycorrhizae in groundnut grown on a calcareous soil. Journal of Oilseeds Research. 13 (1): 61-65.

Sohair K. Saeid, H. M. and Magda, S. (2006). The role of kinetin in flower abscission and yield of Lentil plant. Journal of Applied Science Research. 2 (9): 587-591.

Thakur, M.R., Ulemale R.B and Katore J.R. 2008. Effect of growth regulators and micro nutrient sprays on morpho physiologocal, yield and yield attributes of HPS Groundnut under polytheylene mulch. Annals of Plant Physiology. 22 (1): $46-49$

\section{How to cite this article:}

Menaka, P., Y. Ashoka Rani, K.L. Narasimha Rao, P. Hareesh Babu and Lal Ahamed, M. 2018. Response of Chickpea (Cicer arietinum L.) to Foliar Application of Ethrel, Kinetin and Boron. Int.J.Curr.Microbiol.App.Sci. 7(11): 1653-1660. doi: https://doi.org/10.20546/ijcmas.2018.711.188 